\title{
Natural Coloring as a Coloring Material for Batik Craft in Jepara
}

\author{
Alamsyah $^{1}$, Siti Maziyah ${ }^{2}$, Agustinus Supriyono $^{3}$ \\ \{alam_mahir@yahoo.com\} \\ Universitas Diponegoro, Indonesia ${ }^{1,2,3}$
}

\begin{abstract}
This research, which discussed about natural coloring in batik products in Jepara, used qualitative methods. Data obtained based on observation and interviews with batik craftsmen. The results of the study showed that natural colors were materials that had long been used by craftsmen in batik activities. Along with technological developments, natural coloring was displaced by synthetic coloring, including in the batik process in Jepara. The natural coloring of batik products in Jepara was started to be re-realized in the 2000s as the rise of batik crafts. Along with the rise of batik crafts. In Jepara there were no craftsmen who focused on the natural color usage. Natural coloring used as product samples or made when there were orders from buyers. Although natural coloring product was not routinely made but the natural coloring usage had been implemented by craftsmen in the batik making process. The natural coloring implemented in batik products in Jepara was made of mahogany, teak, papaya leaves, teak leaves, tegeran (Cudrania Javanensis), sapodilla leaves, mango leaves, indigo, etc.
\end{abstract}

Keywords: Color, Nature, Crafts, Batik, Craftsmen, Jepara.

\section{Introduction}

Batik is an Indonesian cultural art work that has value on its appearance beauty and spiritual beauty [1]. In making batik the work that must be carried out including the first, writing or stamping with batik wax, second, giving color to the batik cloth by dipping or sinking (melorod) third, removing batik wax from cloth by scraping or sinking [2]. The materials to make batik before 1900 were mostly from plants because the craftsmen had not used synthetic colors. In its development, natural coloring is shifted by synthetic colors so that the knowledge about natural dyes and how to use it is increasingly being abandoned and more people do not know that at first the natural materials used for coloring batik are soga colors, dark blue or wedelan, added with coloring aids. Soga color can be obtained from tingi tree bark, tegeran wood, and soga jambal bark. Dark blue or wedelan obtained from nila leaves. As for the supporting material for coloring is yellow essence or periwinkle, and pulu flower or kesumba flower [2].

In Jepara the use of natural coloring on batik is not widely used. Batik coloring is still dominated by synthetic coloring. However, natural coloring is sometimes used by craftsmen. Domination using of natural coloring comes from mahogany. Mahogany bark is used because Jepara is the center of furniture and carving craft industry. The raw material for those crafts is mahogany as well as teak. The other natural coloring is by using papaya leaves, teak wood, 
teak leaves, tegeran, sapodilla leaves, mango leaves, indigofera, and etc. But the frequency of using natural coloring is very rare because it depends on consumer orders [3].

Although natural coloring is rarely implemented but most craftsmen already have knowledge about various types of plants around them which can be used as natural coloring materials for batik products. Based on the explanation above, this paper will capture the use of natural coloring in batik crafts in Jepara.

\section{Method}

This research is qualitative research. Data and information collection come from various sources, both literature and locations of the research. The methods used in collecting resources are observation, interviews, and literature studies [4]. Observations is conducted to capture batik craft activities carried out by batik workers and craftsmen in Jepara. From this observation it is seen that batik workers are mostly women aged between 18 to 45 years. Meanwhile the batik craftsmen/craftswomen are mostly between 28 to 52 years old. Interviews were carried out on 9 batik craftsmen in the Jepara area. The batik craftsmen learn from batik business owners. they learn to make batik for about one month. After mastering, they work in craftsmen/craftswomen or independently. From this interview, it can be seen that batik in Jepara is starting to be existed around in the early 2000s. Previously, batik activity had not been seen. The batik coloring is dominated by synthetic coloring. However, natural coloring has been used even though it is rare. The literature study as a secondary source is done by using books about batik, utilizing various national and international journals related to natural coloring. As for the secondary sources are obtained from libraries, private collections, and internet. Various sources that have been available are then criticized and interpreted. The analysis results above are then connected and reconstructed into an article about Colors in Plants as a Material for Coloring Batik in Jepara [5].

\section{Result and Discussion}

\subsection{Natural Color in Jepara}

The process of using natural colors in batik techniques has been carried out for generations. Before the beginning of 20th century, batik craftsmen only made hand-made batik using natural dyes such as teak, noni tree, soga, indigofera, tingi, tegeran, young teak leaves, and other natural materials that have color extracts as needed [6]. Almost all parts of plant when they are extracted can produce dyes, such as flowers, fruit, leaves, seeds, bark, stems/wood and roots. Most natural dyes are belonging to natural mordan dyes. To make the color bound properly, additional materials are needed in the coloring process as the binder or fixator [7]. Since 1996, several European countries such as Germany and Netherlands have restricted clothing, footwear and bed linen products in the use of dyes that containing chemicals for textiles, including batik. Likewise, at the beginning of 21 st century, people start to realize the impact of using synthetic dyes that could interfere with health. Based on those conditions, using natural dyes is one of the promising choices for development in batik coloring [8]. 
Natural coloring in batik is softer than synthetic colors so that it has a high aesthetic value [9]. Some of color carrier materials are used directly, and some of them must be extracted or fermented first. Natural dyes are generally safe and do not cause side effects to the body, safer, and environmentally friendly [10]. Extraction process is by taking pigments or dyes contained in the material. The extraction treatment is through heating by boiling material which carries natural dyes with water is the method that mostly used [11]. Natural dyes obtained from plants are varies such as red, yellow, blue, brown, and black; depending on the type and part of the plant as well as how to get it [7].

Natural coloring is many used by batik craftsmen because the raw materials are available around the craftsmen. Teak leaves can be used as natural coloring because it can produce brown color. Blue, purple, violet, magenta, red, and orange can also be obtained in plant parts such as fruit, vegetables, flowers, leaves, roots, and tubers [12]. Some obstacles to the batik coloring that using natural dyes are the impractical process because it requires a repeated dyeing process. The availability of color variations is rather limited only for bright colors, and the materials availability that are not ready to use. This is what makes special processes and formulation needed so that natural dyes can be used as quality batik dyes. Blue substances are obtained from indigo plants [13]. In order to make batik color is not easily faded and has bright color, so that in the dyeing/coloring process needs to be added a material that can be functioned as a mordant or fixator (fastener) of the dye. Binding materials that are often used in the batik industry such as: lemon, lime, vinegar, belching, borax, alum, lump sugar, brown sugar, palm sugar, tunjung, copper sulphat, drops, lime water, fermented cassava, klutuk banana, guava leaves. The differences of binder material type of natural dyes binder in the cloth coloring process will produces a cloth with different color direction [7].

The use of natural color by Jepara batik craftsmen comes from mahogany bark, tegeran and jambal, tingi wood, mango leaves, indigofera, teak wood, jackfruit's wood, mangos teen and avocado leaves. For brown color, it usually uses mahogany bark, tegeran, and jambal. Yellow is obtained from tingi wood and mango leaves. Blue is obtained from indigofera. Brownish red color is obtained from teak wood. Light yellow is obtained from jackfruit wood. Purplish color is obtained from Mangos teen, and the brownish green color is obtained from avocado leaves ${ }^{1}$.

According to Ahmad Jazuli, making natural dyes for cloth is easy. All plants around us can be used as material for coloring the cloth. The final color obtained depends on the fixation usage. There are three fixation materials used; alum, limestone (we use the water which is used to soak the limestone), and tunjung ${ }^{2}$. Regarding to natural coloring, Lisa uses natural coloring material that available around her house. In her yard there are many different types trees and shrubs. There are two main plants that are used for her natural coloring, they are rose-balsam and mahogany. All plants part of rose-balsam, both stems and leaves used for coloring, while mahogany is only used in the bark part. The color produced by those two materials is brown, but for mahogany the color produced is brighter ${ }^{3}$.

According to Dewi, natural coloring for batik can be obtained from mahogany, beleric myrobalan, and compound cymed mangrove. But mahogany is the material that mostly used. It is because mahogany waste is easily obtained from wood craftsmen in Jepara. It is mahogany bark that can be used as a natural dye. In its utilization process, the bark is boiled for 6 hours, then left overnight. After that it is strained to separate the water from the bark.

\footnotetext{
${ }^{1}$ Interview with Dewi Irawati, June, 2018; Interview with Bowo, June, 2019; Interview with Erlisa, June, 2019; Interview with Alfiyah, June, 2019; Interview with Suyanti, June, 2018).

${ }^{2}$ Interview with Ahmad Jazuli, May, 2018.

${ }^{3}$ Interview with Erlisa, June, 2018.
} 
Then the water can be used to soak the cloth that has been given a batik pattern. Mahogany bark can produce brown color ${ }^{4}$. As for coloring using teak trees and morinda can produce red, while mango tree can produce green. Natural dyes must be locked using alum, limestone, or tunjung, so that the color does not fade. Each locking material produces a different cloth color. Alum produces bright colors, limestone produces medium colors, and tunjung produces dark colors. Besides that, certain amount of each material is needed to obtain the desired color. Natural dyes can be used to dye the cloth for many times. To use it again, the natural dyes are warmed so that the fungus is gone. Batik cloth that colored with natural dyes, requires of up to 10 times soaking process to achieve the desired color. Whereas chemical dyes can produce the desired color only in one soaking5. The natural dye material used by Suyanti is beleric myrobalan and indigofera. She does not use natural coloring too much on her batik production, because she could not cultivate natural dyes material. Natural dyes material that she has ever been used is teak leaves and papaya leaves ${ }^{6}$.

According to batik craftsmen there are several advantages in using natural colors. These advantages are saving capital for raw material because they are available around Jepara there, the selling price of batik becomes more expensive, the color looks more natural, there is a proud feeling for the wearer, the workers are safer and healthier, the color is calm and comfortable to wear, and the feature and the color are more characteristic. Meanwhile the weakness is the production process takes longer, if the cloth treatment is not correct, the batik color will be faded, get less demand in the market because the price is more expensive. The color is less varied, the price of natural dyes is more expensive, it needs extra care so that the color does not fade quickly, and the motifs made is never exactly same between one product to another.

\subsection{Jepara Batik in Natural Coloring}

Batik with natural dyes from Jepara has various prices. The price of stamped-batik with natural dye of Dewi collection is sold for 175 thousand while handmade batik with natural dyes has the lowest price of 300 thousand and the highest price is 1.5 million. While in April collection, the lowest price is 500 thousand and the highest price is 2.5 million. Lina collection, the lowest price is 250 thousand, and the highest price of 1.5 million. High or low prices are influenced by batik motifs, the more complicated the motives, the more expensive the price. Mostly the buyers of handmade batik with natural dyes come from out of Jepara. Batik treatment can be done by not washing it using washing machines and detergents. In drying process, batik should not be exposed to direct sunlight, it just be aerated to dry?

Some batik products made by craftsmen made of mahogany, teak leaves, papaya leaves, indigofera, coconut fibers, mango leaves, sapodilla leaves, and Maclura leaves. Batik products using natural dyes can be seen in the picture below:

\footnotetext{
${ }^{4}$ Interview with Dewi Irawati, June, 2018.

${ }^{5}$ Interview with Dewi Irawati, June, 2018.

${ }^{6}$ Interview with Suyanti, June, 2018.

${ }^{7}$ Interview with Dewi Irawati, June, 2018.
} 
Picture 1. Batik from Natural Dye Ecoprint Motif of Teak leaves and Papaya Leaves, Suyanti Collection

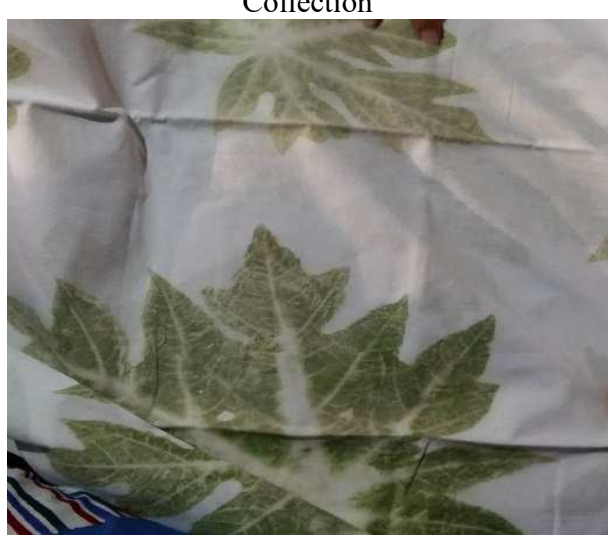

Source: Author's Documentation, 2018.

Picture 3. Batik from Natural Dye Ecoprint Motif of Teak leaves and Papaya Leaves, Suyanti Collection

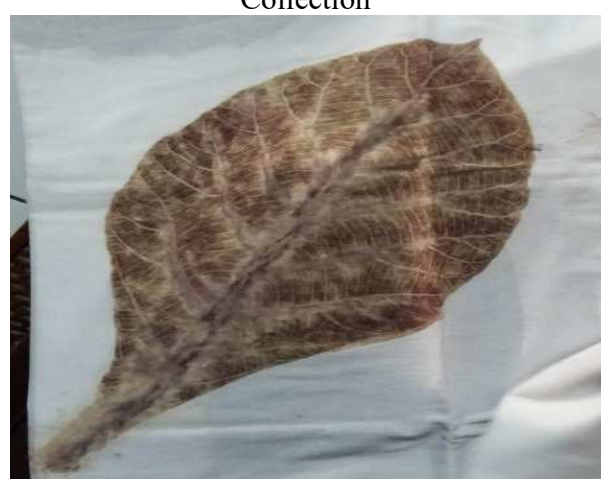

Source: Author's Documentation, 2018.

Picture 4. Batik from Coconut Fiber as Natural Dyes, Dewi Irawati Collection

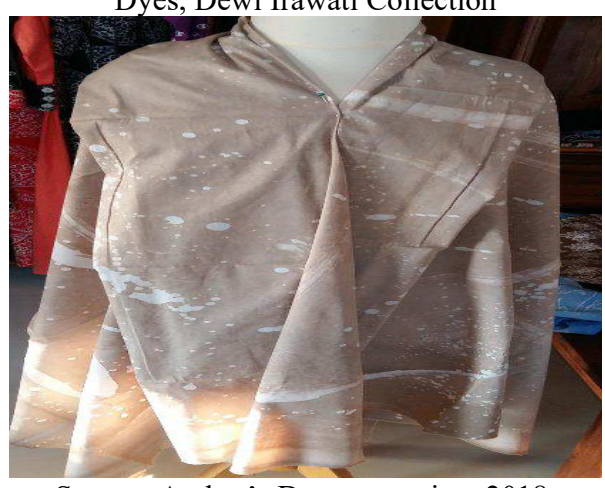

Source: Author's Documentation, 2018.
Picture 2. Batik from Natural Dye Ecoprint Motif of Teak leaves and Papaya Leaves, Suyanti Collection

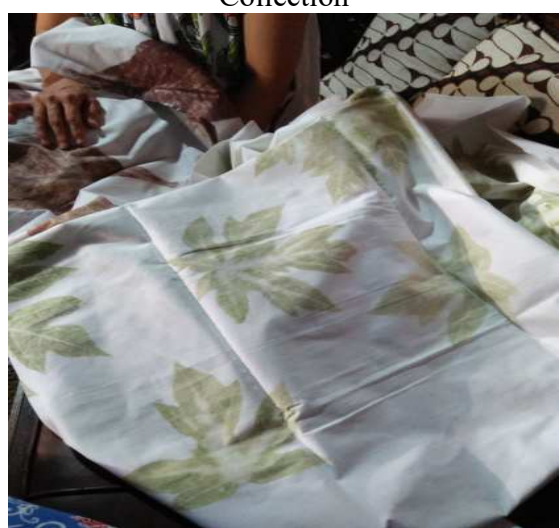

Source: Author's Documentation, 2018.

Picture 4. The natural color of indigofera, the color difference occurs because the dyeing amount is not

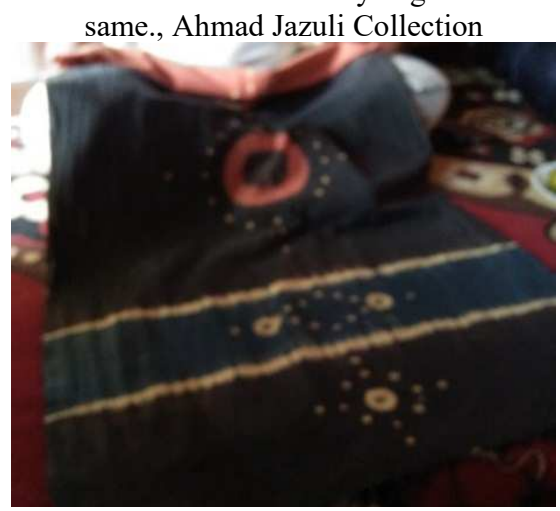

Source: Researcher's Documentation, 2018.

Picture 5. Batik made of Mahogany wood as natural dye, Dewi Irawati Collection

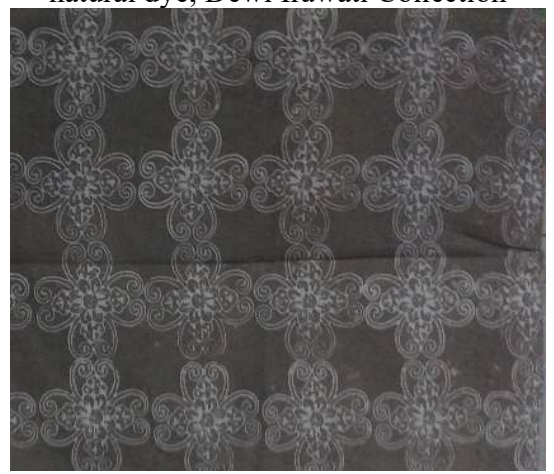

Source: Author's Documentation, 2018. 
Picture 6. Batik Sulur-Suluran made of Mahogany as Natural Dye, Dewi Irawati Collection

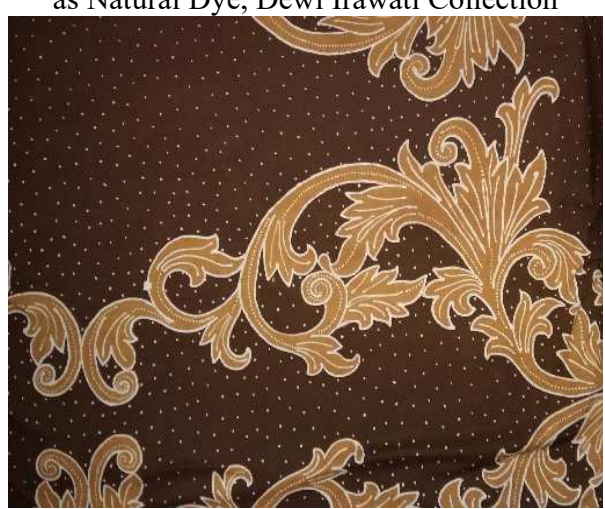

Source: Author's Documentation, 2018.

Picture 8. Batik Sulur-Suluran made of Mahogany wood as Natural Dye, Dewi Irawati's Collection

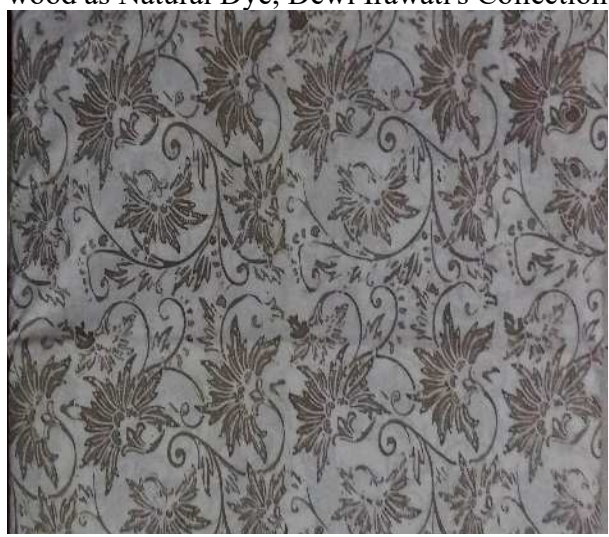

Source: Author's Documentation, 2018.

Picture 10. Blue Natural Dyes made of Indigofera/Tom, and Chocolate from Mahogany

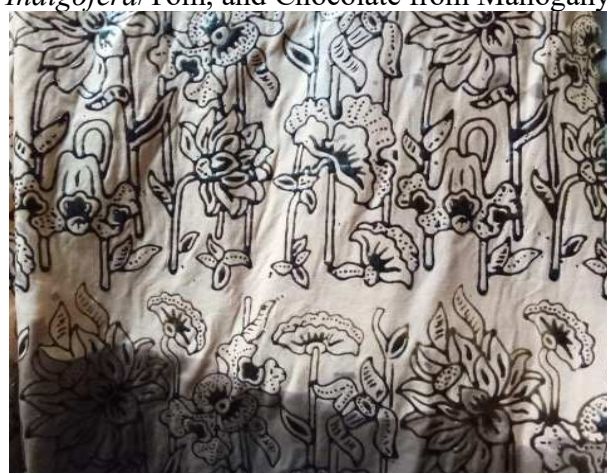

Source: Author's Documentation, 2018.
Picture 7. Batik Sulur-Suluran made of Mahogany as Natural Dye, Dewi Irawati Collection

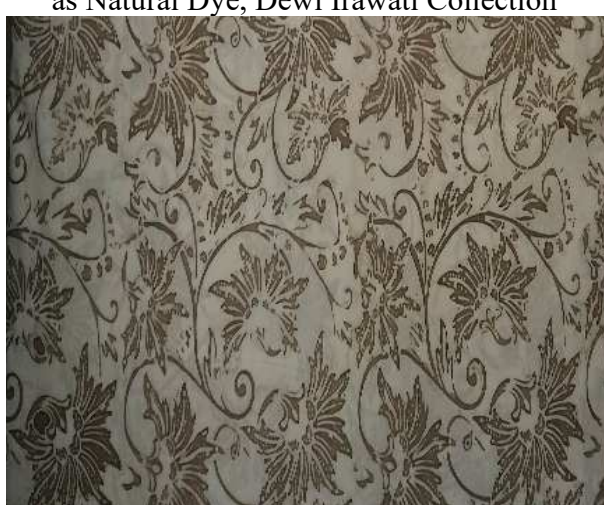

Source: Author's Documentation, 2018.

Picture 9. Batik Product Design made of mahogany bark as Natural Dye made by Researchers

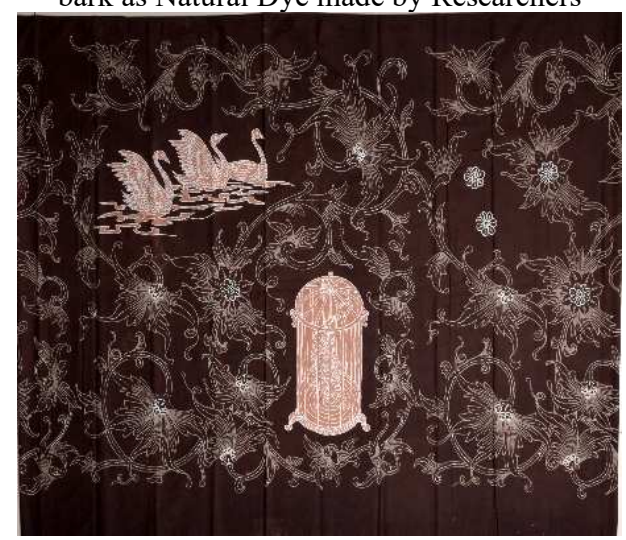

Source: Author's Documentation, 2018.

Picture 11. Natural Dyes made of Mango Leaves with Tunjung Fixation

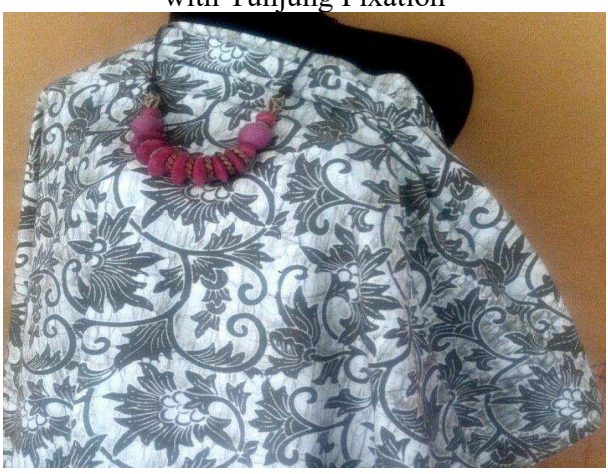

Source: Author's Documentation, 2018. 
Picture 12. Natural Dyes made of Sapodilla leaves

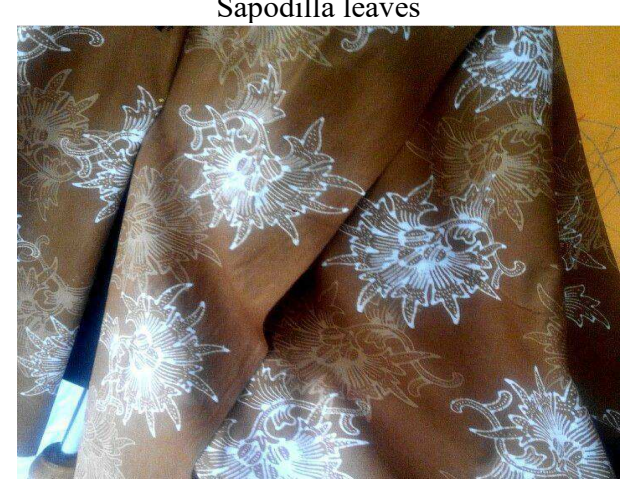

Source: Author's Documentation, 2018.
Picture 13. Natural Dyes made of Maclura wood and Manggo leaves

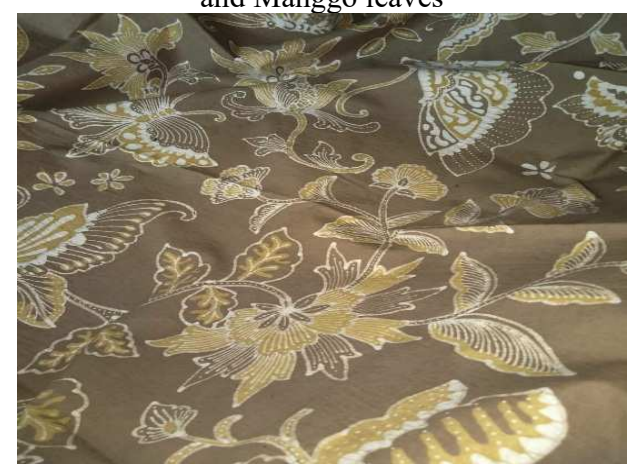

Source: Author's Documentation, 2018.

\section{Conclusion}

The existence of natural colors in batik process in Jepara has been implemented by the craftsmen. Most craftsmen have used natural colors in Jepara batik products, especially mahogany bark with its dominant color, brown. Besides mahogany, there are many natural colors that have been applied to batik products. However, this natural color is not the main raw material, it is usually made only for product samples or when the craftsmen get some orders. The craftsmen actually understand that batik which using natural colors has high economic value and beneficial to the environment. On the other hand, they are realistic because the people who are interested is still very low and mostly from out of Jepara. However, they realized that in the future the use of natural coloring would have bright prospects for the upper middle-class community and foreign market segment.

\subsection{Acknowledgement}

The research is funded by DRPM Dikti in 2019 budget year.

\section{References}

[1] H. S. Doellah, Batik: Pengaruh zaman dan lingkungan. Danar Hadi, 2002.

[2] S. K. S. Susanto, Seni kerajinan batik Indonesia. Balai Penelitian Batik dan Kerajinan, Lembaga Penelitian dan Pendidikan ..., 1973.

[3] B. Bungin, "Metodologi penelitian kualitatif," 2001.

[4] M. Singarimbun, Metode Penelitian Survai.pdf. 1989.

[5] T. Abdullah, "Ke Arah penulisan Sejarah Sosial Daerah," Jakarta Direkorat Jarahnitra. Proy. IDSN, 1984

[6] N. Nurainun, "Analisis industri batik di Indonesia," Fokus Ekon., vol. 7, no. 3, p. 24399, 2008.

[7] T. Pujilestari, "Sumber dan Pemanfaatan Zat Warna Alam Untuk Keperluan Industri," Din. 
Kerajinan dan Batik Maj. Ilm., vol. 32, no. 2, pp. 93-106, 2016.

[8] E. Azizah and A. Hartana, "Pemanfaatan Daun Harendong (Melastoma malabathricum) Sebagai Pewarna Alami untuk Kain Katun," Din. Kerajinan dan Batik, vol. 35, no. 1, pp. 1-8, 2018.

[9] S. Sofyan and F. Failisnur, "Gambir (Uncaria gambir Roxb) sebagai pewarna alam kain batik sutera, katun, dan rayon," J. Litbang Ind., vol. 6, no. 2, pp. 89-98, 2016.

[10] M. Tocharman, "Eksperimen zat pewarna alami dari bahan tumbuhan yang ramah lingkungan sebagai alternatif untuk pewarnaan kain batik," Bandung, UPI, 2009.

[11] A. Alamsyah, "Kerajinan Batik dan Pewarnaan Alami," Endogami J. Ilm. Kaji. Antropol., vol. 1, no. 2, pp. 136-148, 2018.

[12] Y. Satria and D. Suheryanto, "Pengaruh Temperatur Ekstraksi Zat Warna Alam Daun Jati Terhadap Kualitas Dan Arah Warna Pada Batik,” Din. Kerajinan dan Batik, vol. 33, no. 2, pp. 101-110, 2016.

[13] F. Kusumawati, P. H. Riyadi, and L. Rianingsih, "Applications indigo (Indigofera tinctoria L.) as natural dyeing in milkfish [Chanos chanos (Forsskal, 1775)] Skin Tanning Process," Aquat. Procedia, vol. 7, pp. 92-99, 2016. 